症例

鈍的外傷による十二指腸後腹膜破裂の保存的治療の 1 例

徳山病院外科

古 谷 卓 三 赤尾 伸二

外傷性十二指腸破裂は比較的まれな疾患であるが治療困難で予後不良とされている. 今回，外傷性小腸破裂の術後に十二指腸後腹膜破裂に気づき，これに対して保存的治療 を試み救命しえたので，若干の文献的考察を加点報告する。

症例は交通事故にて腹部を打撲した 44 歳の女性で，小腸破裂にて受傷後 2 時間後に手 術を行ったが，受傷後55時間後に十二指腸破裂に気づき意図的に保存的治療を行った。 経過は良好で受傷後24日目に破裂部は閉鎖し，受傷後40日目に退院した。十二指腸破裂 は受傷後より手術までの時間が長いほど予後不良であり，手術が原則とされているが， 十二指腸瘦孔の治療と同様に行えば保存的治療が可能な症例もあると思われた。

索引用語：十二指腸破裂, 鈍的腹部外傷, 保存的治療

はじめに

交通事故や労働災害などによる腹部鈍的損傷は近年 増加傾向にある。このうち, 外傷性十二指腸破裂は, 頻度は低いが治療困難で予後不良とされている.今回, 外傷性小腸破裂の術後に十二指腸後腹膜破裂に気つ き,これに対して保存的治療を試み救命しえたので報 告する。

\section{症例}

患者：44歳, 女性.

主訴: 下腹部痛, 嘔気, 嘔吐.

既往歴：特記すべき事なし。

家族歷：特記すべき事なし。

現病歴：平成 1 年 7 月28日午前 2 時頃, 自動車を運 転中に交差点で他の自動車と衝突し, ハンドルにて腹 部を打撲した。シートベルトは装着していなかった。 受傷直後は腹痛は軽度であったが, 受傷後30分位より 下腹部痛が増強し，胃液様のものを嘔吐したため午前 3 時救急車にて来院した。

入院時現症：意識明瞭で血圧 $114 / 72 \mathrm{mmHg}$, 脈拍 74/分であった。腹部全体に圧痛が著明で, Blumberg 徵候，筋性防禦も認められれた。腸雑音は聴取できな かった。

入院時検査: 血液検査では赤血球数 $440 \times 10^{4} /$ $\mathrm{mm}^{3}$, 白血球数 $14,000 / \mathrm{mm}^{3}$, 血小板数 $23.1 \times 10^{4} / \mathrm{mm}^{3}$ で，貣血は認めなかった。 また，肝機能，腎機能など

1991年 2 月 7 日受付 1991年 7 月 16 日採用
には特に異常を認めなかった。アミラーゼは血中，尿 中ともに正常範囲内であった，検尿にて潜血反応強陽 性であった。

腹部単純 $\mathbf{X}$ 線写真（図 1)：腹腔内遊離ガス像や鏡 面像などは認められなかった。腸腰筋陰影は明膫で, 後腹膜気尰は認められなかった。

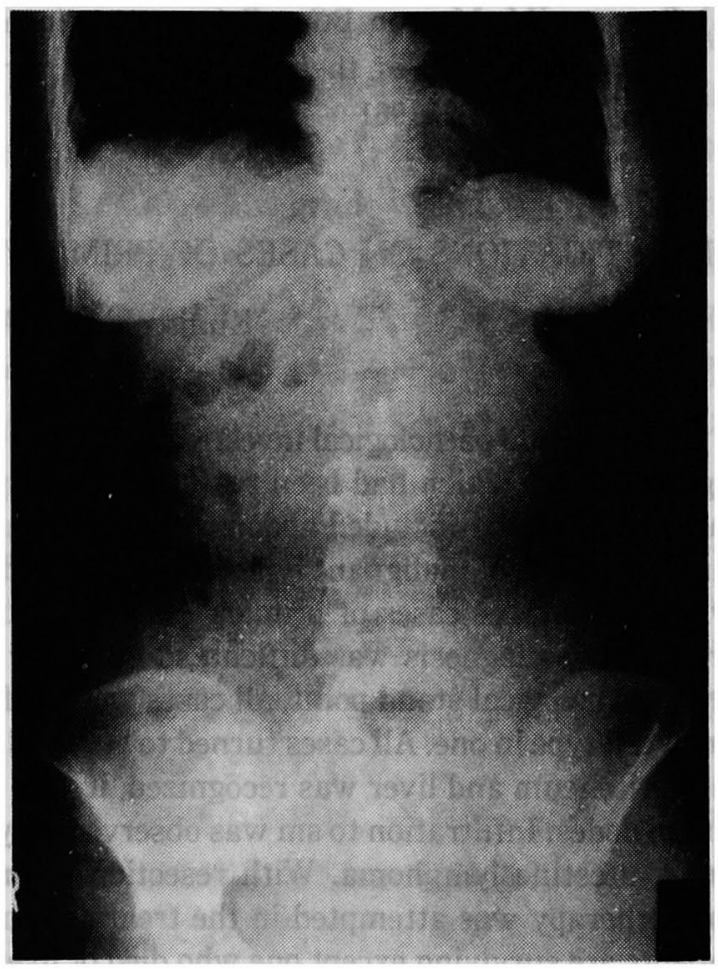

図 1 受鹪時の仰臥位腹部単純 X 線写真：腹腔内遊 離ガス像や後腹膜気腫などは認められなかった。 

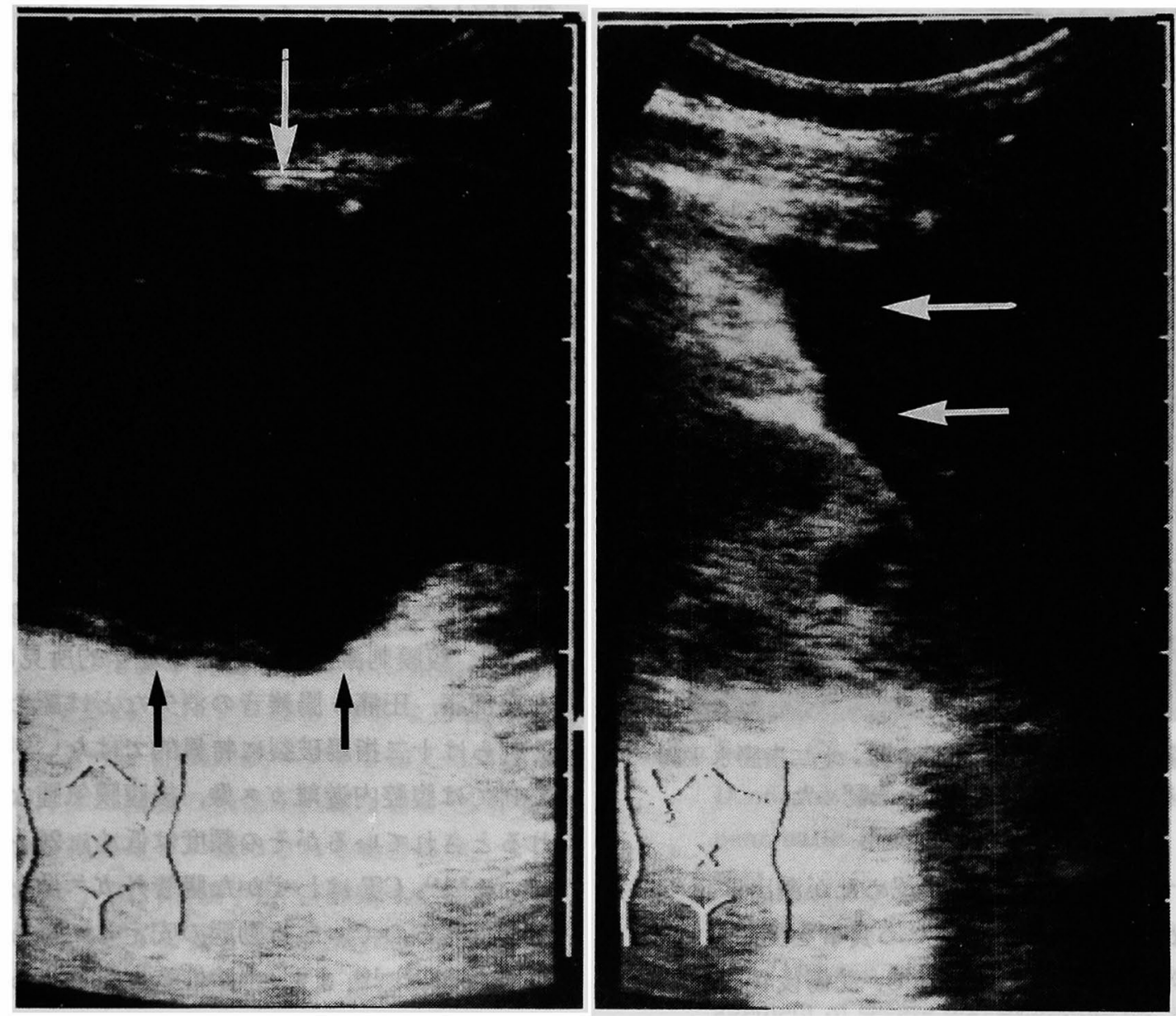

図 2 来院時の腹部エコー：上腹部に払張した胃を認めた。また，モリンン窝に液体 の貯留を認めた。

腹部超音波検查（図 2)：上腹部に巨大な囊胞様陰影 を認めたが，胃内に多量の液体が貯留したものと思わ れた。また，左右横隔腹下腔扰よびモリンン窩に液体 の貯留を認めた。肝，脾，腎および膵に異常所見は認 められなかった。

以上より，外傷性消化管破裂の診断にて受傷後 2 時 間後に緊急手術を行った，なお，腹部 CT 検査および 消化管造影は行わなかった。

手術所見：臍下におよぶ上腹部正中切開にて開腹し た。肱上部に皮下出血を認め，打撲部は臍上部と推定 された. 腹腔内に約 $500 \mathrm{ml}$ の出血を認めた。トライッ靯 帯より約 $70 \mathrm{~cm}$ 肛側の空腸に約 $2 / 3$ 周にわたる裂創を 認め, 挫滅部を含め腸の一部を切除後 2 層に縫合閉鎖 した。 またこれょり約 $5 \mathrm{~cm}$ 肛側の腸間膜に約 $7 \mathrm{~cm} に$ わたる裂創を認め，同部より出血を認めたため修復止 血した，腸間膜根部に血腫を認めたがすでに止血して おり放置した，子宮笳腫および右卵巣票腫を認めたが, 肝, 脾, 膵などに異常は認めなかった。 十二指腸に軽
度の浮腫を認めたが, Kocher 十二指腸授動術は行わ なかった. 腹腔内を洗浄後, モリンン窩, 左横隔膜下 腔およびダグラス简にペンローズドレーンを留置し手 術を終了した。

術後経過：2 日間軽度の発熱を認めたが, 経過は良 好であった。受傷後55時間後に経鼻胃管より造影を 行ったところ, 十二指腸水平脚部より後腹膜腔に造影 剂の漏出を認めた（図 3)，受傷後よりかなり時間が経 過していたが, 全身状態は良好で, 腹膜刺激症状, 発 熱および白血球増多などの所見を認めず，さらに受傷 時より胃内に食物残渣を認めなかったことなどによ り, 保存的に治療を行らことにした. 完全静脈栄養と し, 胃管を18Fr，のイレウス管と入れ替え，十二指腸ま で挿入しドレナージとした. イレウス管の持続吸引は 行わなかったが、イレウス管よりの排液量は一日 $200 \sim 1000 \mathrm{ml}$, 平均約 $400 \mathrm{ml}$ 位であった. 受傷後 10 日目 の造影では造影剤の漏出は少なくなったが, 受傷後 15 日目の造影でるまた漏出を認めた(図 4 左)。受傷後 24 


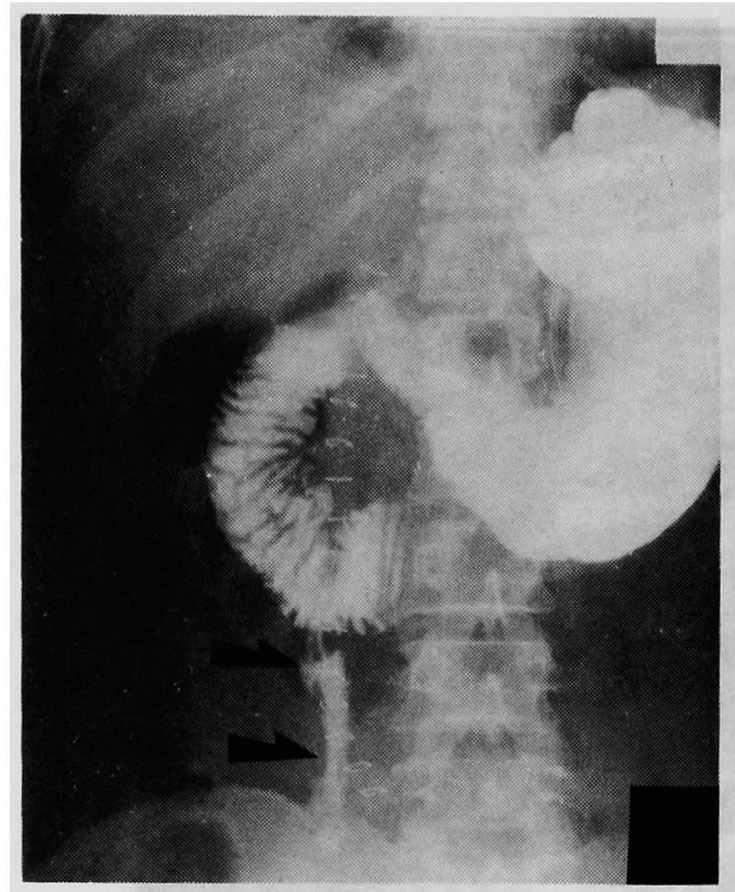

図 3 受盷後55時間の十二指腸造影：十二指腸水平脚 部より後腹膜腔に造影剤の漏れを認めた。

日目の造影では壁の不整を軽度認めたが漏出は認めら れず，狭窄などす認めなかったため食事を開始した(図 4 右). 食事開始後す経過は良好で, 受傷後40日目に軽
快退院した。

考案

十二指腸損傷は消化器外傷の約 $10 \%$ 位で比較的まれ な疾患である゙。しかし，診断扣よび治療が難しく，そ の死亡率は12３5\%と高い2) 5). 本邦ではそのはとん ぞが鈍的損傷である゙が，欧米では銃創，刺創が多く， 鈍的損傷は全体の13 35\%である2) 5). 鈍的損傷の原 因としては交通事故がはとんどである(4)7 -9). 十二指腸 鈍的損傷の機転として, (1)椎体による王挫説, (2)固定 された十二指腸に働く引き裂く力説, (3) Closed duodenal loop 説などが考古られており ${ }^{110111}$, これら が組合わさって十二指腸損傷をきたすとされてい る7)12). あり，十二指腸鈍的損傷では第 $2 ， 3$ 部の破裂が多い ため ${ }^{8)}$, 腹膜刺激症状が出難く理学的所見に乏しい. ${ }^{13)}$. 上腹部痛, 王痛, 腸雑音の消失などは認められるか;, それらは十二指腸破裂に特異的ではない13). 腹部単純 $\mathrm{X}-\mathrm{P}$ では腹腔内遊離ガス像, 後腹膜気腫などが認めら れるとされているがその頻度は低く，20～40\%とされ ている8114). CT はわずかな腸管外ガス像を診断するこ とができるので，血行動態の安定している患者では有 用である(6)13) 16). .た, 水溶性造影剤による消化管造影
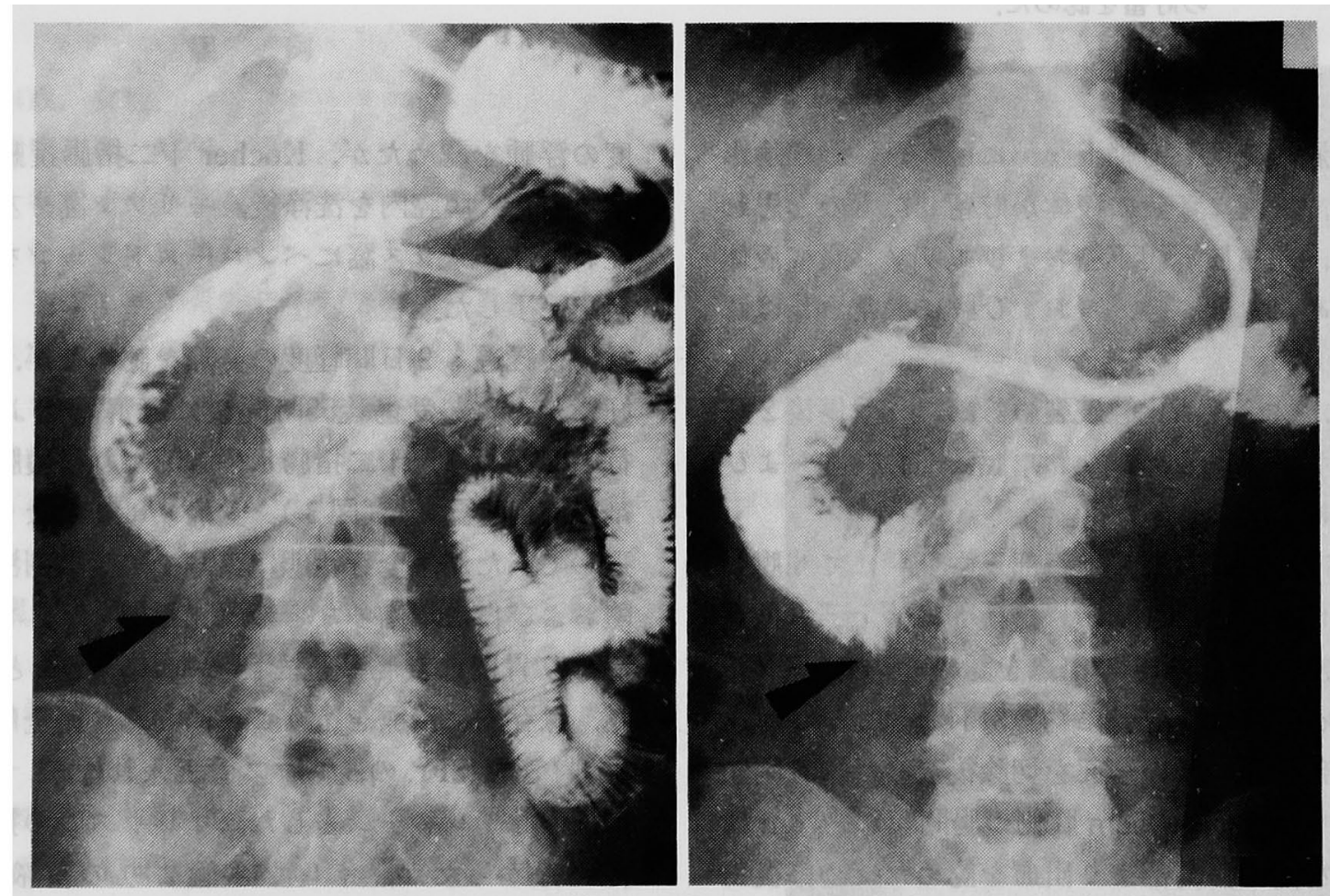

図 4 左 受傷後14日目の十二指腸造影：まだわずかに造影剂の漏れを認めた。

図 4 右 受傷後24日目の十二指腸造影：造影剤の漏れは認められず，㹟窄などあ認め られなかった。 
も有用であるが，全例に施行できるわけではない16).

このように，鈍的外傷にともなら十二指腸破裂の診 断は難しく，受傷から手術までの時間が長いはと予後 が悪いとされている(47)8177). また, 腹腔内の他葴器合併 損傷に注意を奪われることやその解剖学的理由などに より，十二指腸後腹膜破裂が見逃されることがある。 一旦開腹時に見逃されると，術後状態と重なりさらに 治療が暑れ ${ }^{8100}$ ，不幸な転㷌をとるとされている57。開 腹時に十二指腸破裂を疑う所見としては，後腹膜の気 腫, 胆汁染，浮腫や出血などがある(7)8).しかし，この ような所見す全ての症例に認められるわけではなく， Kocher や Cattell \& Braaschの方法により十二指腸 を露出し確認する必要がある18)18).

十二指腸破裂の修復法としては種々なる方法が報告 されている．十二指腸単純縫合術は十二指腸破裂の 70 85\%に施行されており，最も簡単な方法であ る4)191. また，これに，空腸漿膜パッチを加える方法も ある ${ }^{19)}$. しかし，十二指腸の損傷か広範な場合や，膵管， 胆管などの合併損傷などが認められる場合には，十二 指腸䅨室化手術 ${ }^{2}$ ，幽門閉鎖手術 ${ }^{3}$ ，膵頭十二指腸切除 術尚などの手術方法が必要となる. Snyder ら゙は十二 指腸破裂を 5 項目の判定基準により重症と軽症に分 け，重症例には十二指腸㮩室化手術などの複雑な手術 方法を行っている。 また, Lucas $5^{17) p ~ M a n s o u r ~} 5^{201}$ は，十二指腸，膵管，胆管の損傷程度により 4 または 5 段階に分け，適切なる手術術式を決めている。

他藏器合併損傷などによる死亡例を除けば，十二指 腸瘦孔形成が合併症として最も重要である4). 腸管の 浮腫や蠕動運動の低下により腸管内に液体の貯留がお こり腸管内压が上昇することが十二指腸㿉孔の原因と されている57). このため術後 $5 \sim 7$ 日間位十二指腸减 王を行らべきである゙．しかし，それでる十二指腸㾇孔 を形成した場合，死亡率は40４4\%となるとされてい る45). 瘦孔の治療方針としては, 减圧, ドレナージ， $\mathrm{H}_{2}$ ブロッカーの投与などがある7が，4〜6週で閉鎖 しなければ手術にふみきるべきとされている7゙。

この症例では小腸破裂にて受傷直後に手術を行った が，受傷後55時間経過して十二指腸破裂に気付き，意 图的に保存的治療を試み破裂部を閉鎖することができ た. Lucas らの分類の class 1，とくに小児の十二指腸 血尰では保存的に治療するのが一般的である1721)221 が，この症例は class 2の破裂であり，保存的治療の適 応ではなかった。しかし，受傷後かなり時間が経過し ていたにもかかわらず全身状態は良好で，腹膜刺激症
状，発熱および白血球増多などの所見を認めず，さら に受傷時より胃内に残椬を認めず絶食としていたなど の理由より，十二指腸瘦孔形成例と同様に保存的に治 療を行らことにした。後腹膜にドレナージを行ってい なかったにもかかわらず受傷後24日目に閉鎖すること ができた。瘦孔形成時と注ぼ同じ治療を行らことによ $\eta$, 十二指腸破裂の一部では保存的治療が可能な症例 もあると思われた。

結 語

鈍的外傷による十二指腸破裂に受傷後55時間後に気 づき，保存的治療を施行し救命しえた症例を経験した ので，若干の文献的考察を加え報告した。

\section{文献}

1) DeMars JJ, Bubrick MP, Hitchcock CR: Duodenal perforation in blunt abdominal trauma. Surgery $86: 632-638,1979$

2) Berne CJ, Donovan AJ, White EJ, et al : Duodenal "diverticulization" for duodenal and pancreatic injury. Am J Surg 127: 503-507, 1974

3) Vaughan GD III, Frazier OH, Graham DY, et al: The use of pyloric exclusion in the management of severe duodenal injuries. Am J Surg 134 : 785-790, 1977

4) Snyder WH III, Weigelt JA, Watkins WL, et al : The surgical management of duodenal trauma: Precepts based on a review of 247 cases. Arch Surg 115 : 422-429, 1980

5) Corley RD, Norcross WJ, Shoemaker WC: Traumatic injuries to the duodenum : A report of 98 patients. Ann Surg 181: 92-98, 1975

6）板野 聡，寺田紀彦，橋本 修他：外傷性十二指腸 破裂の 1 症例一術前 computed tomography 検查 の有用性について一，日消外会誌 $22: 835-838$, 1989

7) Weigelt JA : Duodenal injuries. Surg Clin North Am 70 : 529-539, 1990

8) Fabian TC, Mangiante EC, Millis $M$ : Duodenal rupture due to blunt trauma : A problem in diagnosis. South Med J 77 : 1078-1082, 1984

9) McAnena OJ, Moore EE, Marx JA: Initial evaluation of the patient with blunt abdominal trauma. Surg Clin North Am 70 : 495-515, 1990

10) Cocke WM, Meyer KK: Retroperitoneal 
duodenal rupture : Proposed mechanism, review of literature and report of a case. Am J Surg $108: 834-839,1964$

11) Cleveland HC, Waddell WR: Retroperitoneal rupture of the duodenum due to nonpenetrating trauma. Surg Clin North Am $43: 413-431,1963$

12) Phillips TF, Brotman $S$ : Perforating injuries of the small bowel from the abdominal trauma. Ann Emerg Med $12: 75-79,1983$

13) Maull KI, Rozycki GS, Vinsant GO, et al : Retroperitoneal injuries: Pitfalls in diagnosis and management. South Med J $80: 1111-1115$, 1987

14) Cook DE, Walsh JW, Vick CW, et al: Upper abdominal trauma: Pirfalls in CT diagnosis. Radiology 159 : 65-69, 1986

15) Glazer GM, Buy JN, Moss AA, et al: CT detection of duodenal perforation. AJR $137: 333$ $-336,1981$

16) Meredith JW, Trunkey DD: CT scanning in acute abdominal injuries. Surg Clin North Am $68: 255-268,1988$

17) Lucas CE, Ledgerwood AM : Factors influencing outcome after blunt duodenal injury. J Trauma $15: 839-846,1975$

18) Cattell RB, Braasch WB: A technique for the exposure of the third and forth portions of the duodenum. Surg Gynecol Obstet $111: 378-379$, 1960

19) McInnis WD, Aust JB, Cruz AB, et al : Traumatic injuries of the duodenum : A comparison of $1^{\circ}$ closure and the jejunal patch. J Trauma $15: 847-853,1975$

20) Mansour MA, Moore JB, Moore EE, et al: Conservative management of combined pancreatoduodenal injuries. Am J Surg 158: 531 $-535,1989$

21) Pokoeny WJ, Brandt ML, Harberg FJ : Major duodenal injuries in children : Diagnosis, operative management, and outcome. J Pediatr Surg $21: 613-616,1986$

22) Maull KI, Fallahzadeh H, Mays ET : Selective management of post-traumatic obstructing intramural hematoma of the duodenum. Surg Gynecol Obstet 146:221-224, 1978

\title{
NON-OPERATIVE MANAGEMENT OF THE DUODENAL RUPTURE DUE TO BLUNT TRAUMA - REPORT OF A CASE-
}

\author{
Takumi FURUYA and Shinji AKAO \\ Department of Surgery, Tokuyama Hospital
}

Duodenal rupture due to blunt trauma is a rare disease, and it has a high mortality rate. Non-operative management of blunt duodenal rupture was performed successfully.

A forty-four year-old-woman, who got a bruise on the abdomen at traffic accident, was operated on for ruptured small intestine 2 hours after the accident, and duodenal rupture was recognized 55 hours after the accident. Intentional non-operative management of the duodenal rupture was performed. Rupture of the duodenum was closed 24 days after the accident and the hospital stay amounted to 40 days.

Operation is commonly recommended for rupture of the duodenum, and delayed operation can cause poorer prognosis. However, in some cases, non-operative management which is the same as duodenal fistula is treated can be successfully performed. 